\title{
セグメント間の加減速運動に起因するマシニングセンタの 直線補間工具経路の誤差推定*
}

\author{
丘 \\ 華*1, 久保 明 雄*1, 岡 本 経 寿*2 $^{* 2}$
}

\author{
Error Estimation to Linear Interpolation Cutter Path of \\ Machining Center due to Acceleration/Deceleration Motions \\ between Two Interpolation Segments
}

\author{
Hua QIU*3, Akio KUBO and Norihisa OKAMOTO \\ ${ }^{* 3}$ Department of Mechanical Engineering, Kyushu Sangyo University, \\ 2-3-1 Matsukadai, Higashi-ku, Fukuoka-shi, Fukuoka, 813-8503 Japan
}

\begin{abstract}
This paper proposes a practical approach to estimating the path errors produced by the NC acceleration/deceleration motions around connection points between every two segments for a linear interpolation cutter path of a machining center. The approach consists of two parts. The first is an experimental method to identify the value of each related parameter in NC appareture to the acceleration/deceleration motion control, in which only an operation is needed to measure a few simple motion trajectories with two linear segments with the machining center. The other part is a concise and efficient simulation algorithm based on the identification results for a cutter path composed of a number of short linear segments. A comparison result of the simulated cutter path trajectories with the measured ones and contours of machined work pieces sufficiently demonstrates the effectiveness and reliability of the proposed approach. Therefore, as a useful tool, the approach is applicable to beforehand estimating the influence of the $\mathrm{NC}$ acceleration/deceleration motions on cutter path accuracy or judging the cutting conditions for the machining purpose without performing an actual machining test with the machining center.
\end{abstract}

Key Words : Machining Center, Cutter Path, Motion Trajectory, Error Estimation, Parameter Identification, Linear Interpolation, Acceleration/Deceleration Control, Simulation

\section{1. 粕 言}

マシニングセンタ（以下，MC と略す）の工具経路を 直線で補間する場合，二つの補間セグメントの間にド ウェルを設けなければ，加工されたワークの輪郭はシ ヤープな形にならず丸みを持つ形状になることがよく 知られている(1).(2). その原因はセグメント間の NC 加減 速運動（以下，加减速運動と略す）である。セグメン トが長い場合，丸み誤差（コーナ部誤差）は前後のセ グメント間のつながり部のみに現れ，その大きさと形 状は MC の NC 装置内部に用いた加減速運動の制御則 と工具送り速度の值によって決まる ${ }^{(3)-(5)}$. したがって, $\mathrm{NC}$ 装置内部の加減速制御の方式と関連パラメータの 值がわかれば，切削実験せずに切削条件に対応するコ

\footnotetext{
* 原稿受付 2010 年 3 月 29 日.

*1 正員, 九州産業大学工学部(恶 813-8503 福岡市東区松香台 2-3-1).

*2 九州産業大学大学院工学研究科[現：大分キヤノン(株) (业) 873-0292 国東市安㞳町下原 710)]

E-mail : chiu@ip.kyusan-u.ac.jp
}

一十部誤差を把握することができる、しかし，通常で は MC の使用者にとってこのような NC 装置内部制御 方式の詳細とパラメータの値は開示されていない.

一方，曲線輪郭を精密に加工する場合は，補間セグ メントが短く設定されるので, セグメント間の加減速 運動は前後のセグメントのつながり部だけでなく，後 続するセグメントまでに影響を及ぼすことがある。こ の場合, セグメント間の加減速運動は輪郭全般の精度 に影響することとなる。しかし，この問題に関する研 究はあまり公表されていない(6).

以上のことをふまえて，本研究では，まず極少回数 の簡単な MC 直線補間運動の軌跡を測定し，その結果 から補間セグメント間の NC 加減速連動制御パラメー 夕を同定する方法を提案する．また，同定結果を用い て推定した工具経路の軌跡を実測した MC の連動軌跡 と比較し, 提案方法の有効性を確認する. 次に, 多数 の短い直線セグメントからなる工具経路を対象とし， MC の加減速運動制御パラメータに基づいて, 工具経路 
軌跡のシミュレーション方法を提案する.さらに，シ ミュレーションした工具経路の軌跡結果を実測した MC の運動軌跡および加工したワークの実測輪郭と比 較することにより，提案方法の妥当性を示す.

\section{2. 加減速通功制御パラメータの同定法}

2・1 直線補間远功によるコ一ナ部虽差 図 1 に MC の直線補間運動におけるコーナ部誤差の発生機構 を示す．図中の $x$ 軸と $y$ 軸は運動平面を構成する $\mathrm{MC}$ の第 1 と第 2 の駆動軸である. 点 $S$ から点 $A$ まで送り 速度 $v_{1}$ で，点 $A$ から点 $E$ 一送り速度 $v_{2}$ で直線補間運動 を指令する場合，セグメントの接続点 $A$ でドウェルを 設けなければ， $\mathrm{MC}$ の寒運動軌跡は点 $A$ のまわりに図 示するような近回りの形になり，加工されたワーク輪 郭はシャープな角を持たずに丸みを帯びた形状になる. このコーナ部誤差の形成は, 前のセグメントが点 $A$ よ り前の点 $B$ で減速し始め，わずかに遅れて次のセグメ ントが点 $A$ より前の点 $C$ で加速し始めるからである. 図 2 に示すように，点 $A$ まわりの二つのセグメント接 続部における $x$ 軸の送り速度成分 $v_{x}$ は， $v_{1 x}$ から 0 への 减速運動および時間 $\Delta t$ 遅れて開始する 0 から $v_{2 x}$ への加 速連動の合成運動速度になる ${ }^{(4)} . y$ 軸の送り速度成分 $v_{y}$ の変化も類似する形になる. その結果, $\mathrm{MC}$ の実連動軌 跡には図 1 に示すようなコーナ部誤差が発生する.

したがって，使用する MC の各サーボ軸（駆動軸） のセグメント接続点間の NC 加减速運動制御方式とタ イミングパラメータがわかれば、コーナ部誤差を推定 することができる.

$2 \cdot 2$ 供試 MC の加減速远的制御パラメータ 本 研究に対象とする MC はワシノ製のセミクローズドル 一プ方式の WMC-4 立形中型 $\mathrm{MC}$ である. その $X$ 軸， $Y$ 軸, $Z$ 軸の移動範囲はそれぞれ $900 \mathrm{~mm}, 450 \mathrm{~mm}, 510 \mathrm{~mm}$ である. NC システムはFANUC Series 0-MB であり， 同時制御軸数は 2.5 軸，最小設定単位は $1 \mu \mathrm{m}$ である. テーブルの案内方式は滑り案内であり，テーブルの構 造は $X$ 軸テーブルが $Y$ 軸テーブルの上に載せられた構 造である. また，最大切削送り速度は $5000 \mathrm{~mm} / \mathrm{min}$ で ある.

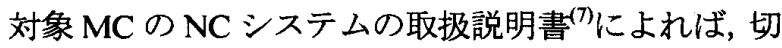
削送りの加減速連動制御は指数関数形加減速方式が採 用されている.それに基づいて，本研究では駆動軸が $v_{0}$ から0に減速するときの送り速度 $v$ について次式で定 義する.

$$
v=v_{0} e^{-\frac{t-r_{1}}{r}}
$$

また，駆動軸が 0 から $v_{0}$ へ加速するときの送り速度 $v$

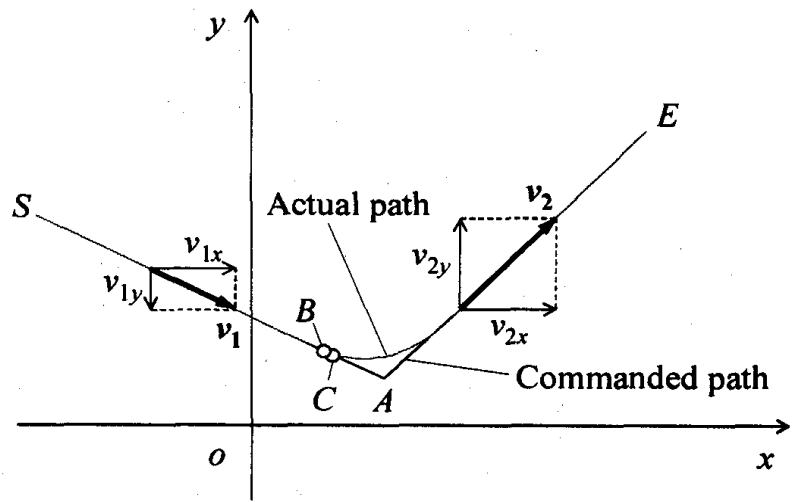

Fig. 1 Corner error

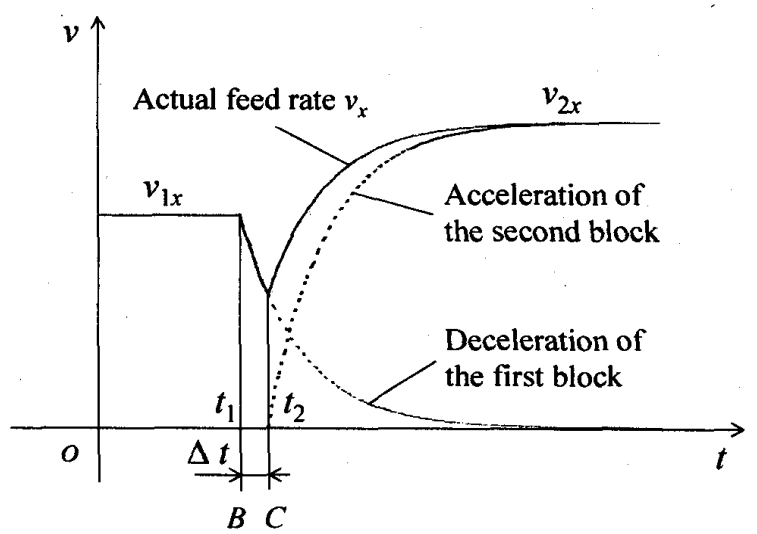

Fig. 2 The $x$ axis feed rate change between two segments

については次式で定義する。

$$
v=v_{0}\left(1-e^{-\frac{t-t_{2}}{T}}\right)
$$

ここで, $t$ は時間, $T$ は駆動軸サ一ボ系の時定数, $t_{1}$ と $t_{2}$ は加減速運動制御のタイミングパラメータである.

タイミングパラメータ $t_{1}$ の值について次のような仮 定をする. 駆動軸は現在の速度 $v_{0}$ から 0 八减速して, 速度が 0 になったときにセグメントの指令位置に到達 することとする，したがって，減速運動に対する駆動 軸の通過距離 $l$ は次式となる.

$$
l=\int_{0}^{\infty} v_{0} e^{-\frac{t}{T}} \mathrm{~d} t=v_{0} T
$$

この関係から, 駆動軸が $v_{0}$ の速度で $l$ を通る時間は $T$ で あることがわかる．したがって，駆動軸が $v_{0}$ の速度で セグメントの指令終点に到達する時刻 $t_{0}$ から $T$ を引く 時刻は减速の開始時刻となる.すなわち,

$$
t_{1}=t_{0}-T
$$

一方, タイミングパラメータ $t_{2}$ は $\mathrm{NC}$ 装置内部のセ グメント処理に関係するパラメータであり, 図 2 に示 した関係から次のように表される。

$$
t_{2}=t_{1}+\Delta t
$$


したがって，供試 MC の NC 加減速運動制御パラメ 一タは $X$ 軸, $Y$ 軸と $Z$ 軸サーボ駆動系の時定数 $T_{x}, T_{y}$, $T_{z}$ および各軸に対応する $\Delta t$ である.

$2 \cdot 3$ 制御パラメータの同定实験と結果検証 供 試 MC の加減速運動制御パラメータの值を定めるため に，既報の LM（Link Mechanism）測定装置 ${ }^{(8)(9)}$ を使用 して, $\mathrm{MC}$ の $X Y$ 平面と $Y Z$ 平面に図 3 に示す直角運動 軌跡をそれぞれ一回測定する，図中の座標系は LM 測 定装置の測定座標系 ${ }^{(8)(9)}$ である. 実験に使ったデータ記 録サンプリングタイムを用いて運動軌跡の座標デ一タ について数值微分をすると, 各軸の送り速度成分を得 ることができる ${ }^{(10)}$.さらに，各軸の送り速度成分デー タについて最小二乗法を使用し，式(1)と（2）に基づい てパラメータの最適值推定を行うことにより, 各軸の 時定数とタイミングパラメータ $\Delta \boldsymbol{U}$ の值を決める.

測定実験において，運動軌跡のサンプリングタイム を $480 \mu \mathrm{s}$ に設定し, 運動軌跡にそって約 2000 点の座標 を記録する. 図 4 に同定実験の結果を示す。供試 $\mathrm{MC}$ の場合, 各軸の $\Delta t$ は同じ $0.007 \mathrm{~s}$ であり, $T_{x}, T_{y}, T_{z}$ の 值はそれぞれ $0.0210 \mathrm{~s}, 0.0201 \mathrm{~s}, 0.0208 \mathrm{~s}$ である.一方， 図中には同定した $T_{x}, T_{y}, T_{z}$ および $\Delta t$ の值を用いて推 定した送り速度成分 $\dot{X}, \dot{Y}, \dot{Z}$ も示している. 推定曲 線と実測デ一タによる曲線がよく一致していることか ら，同定結果は良好であると思われる。

同定結果の妥当性を検証するために, $M C$ の $X Y$ 平面, $Y Z$ 平面, $X Z$ 平面において図 5 に示す検証運動経路を NCプログラムにして MC の運動軌跡を測定した. 各検 証経路は点 $A$ から, 順次点 $B$, 点 $C$, 点 $D$, 点 $A$ を通 って, 点 $B$ で止まる. また, 連動軌跡について等時間 間隔で約 7750 点を記録した.

図 6 に角部の実測運動軌跡および同定パラメータに よって推定した運動軌跡, 図 7 には実測データの数值 微分による軸の送り速度成分と同定データによる送り 速度成分との比較例を示す.いずれの場合においても 推定曲線は実験による曲線とよく一致している。ただ し, 図6のコーナ $A$ とコーナCの拡大図に示すように, 推定した運動軌跡のコーナ部半径は実測した運動軌跡 のそれよりやや小さくなり, 位置も実測軌跡の外側に なっている、両方の位置における最大差は, コーナ $A$ では約 $45 \mu \mathrm{m}$ 程度, コーナCでは約 $20 \mu \mathrm{m}$ 程度である. この違いは供試 MC 駆動軸の運動方向の逆転における ロストモーションやバックラッシュ補正などの影響に よるものと思われる(8),(9),(11). ほかの連動平面に施した実 験の結果も同様である.この結果から，提案した NC 装置内部の加減速運動制御パラメータの同定法および 式(3)の仮定は妥当であることがわかった.

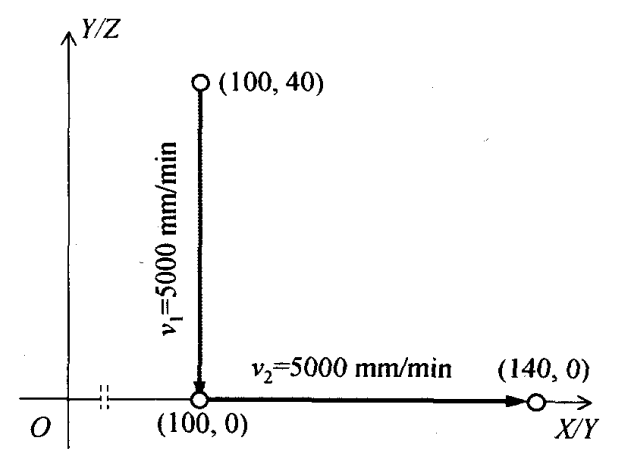

Fig. 3 Test path in the identification experiment
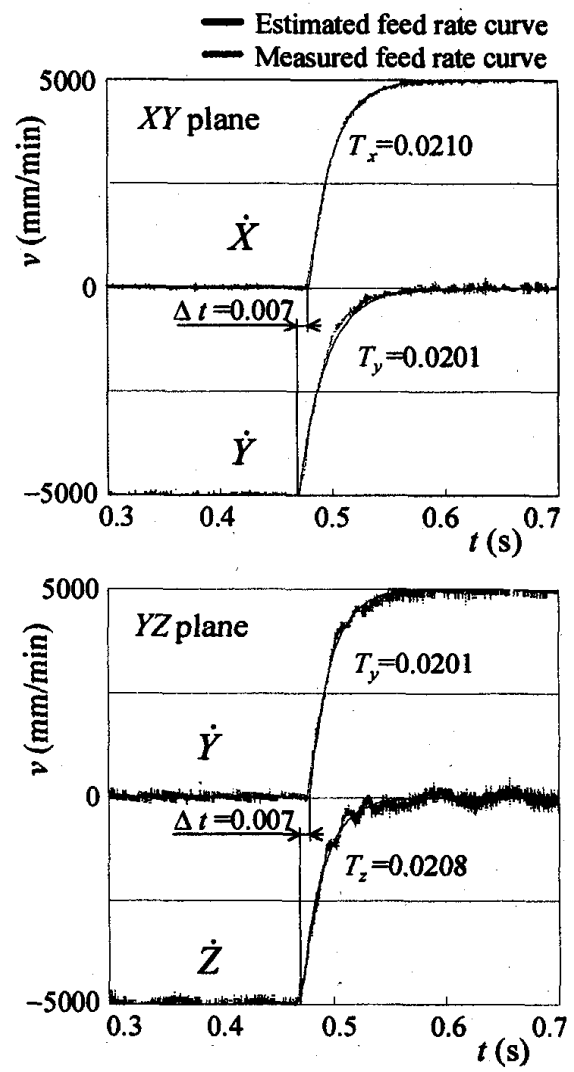

Fig. 4 Results of the identification experiments

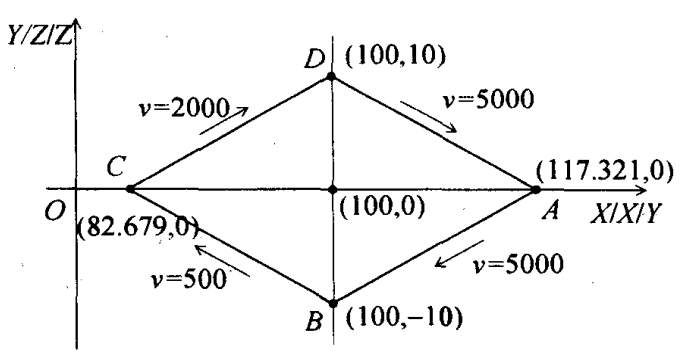

Fig. 5 Test path to verify the identification result

以上では，指数関数形の加減速運動制御方式を例と して NC 加減速運動制御パラメータの同定法を説明し たが，この基本的な考え方はほかの加減速連動制御方 式(4)にも適用できると思われる.また，MCの運動軌跡 の測定に当たっては，交差格子スケール（クロスグリ 


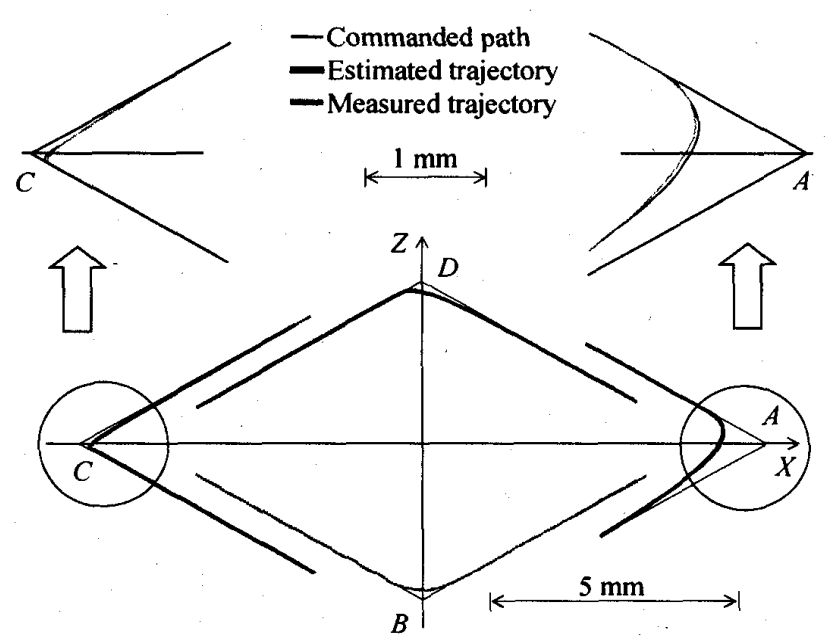

Fig. 6 Motion trajectory results in verification experiments

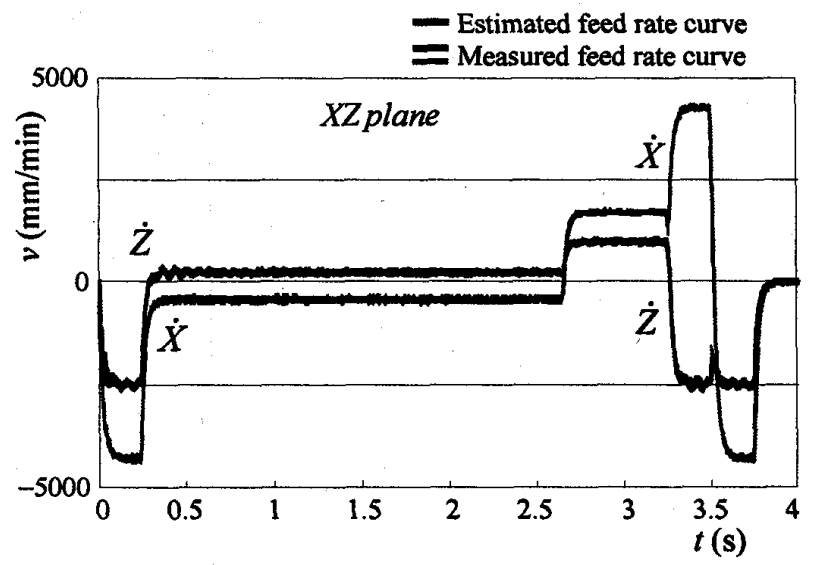

Fig. 7 Feed rate results in verification experiments

ッドエンコーダとも呼ばれる) による方法(12),(13)，また は, NC 装置のフィードバック信号をモニターする方法 ${ }^{(13),(14)}$ の利用も可能である.

\section{3. エ具経路軌跡のシミュレーション方法}

図 8 に示す MC の工具経路はつながり点でドウェル を設けない $n$ 個の直線セグメントで構成される．指令 位置として工具経路の開始点を $A_{0}\left(X_{0}, Y_{0}\right), i$ 番目セグメ ント $(i=1,2, \ldots, n)$ の終了点を $A_{i}\left(X_{i}, Y_{i}\right)$ とする. 点 $B_{i}\left(x_{B i}\right.$, $\left.y_{B i}\right)$ は $i$ 番目セグメントの減速運動開始点, 点 $C_{i}\left(x_{C i}, y_{(i)}\right)$ は $i+1$ 番目セグメントの加速運動開始点である. $i$ 番目 セグメントの指令送り速度を $F_{i}$ とすると，それに対応 する駆動軸 $x$ と $y$ の公称送り速度 $F_{i, x}$ と $F_{i, y}$ は次式によ る.

$$
\left\{\begin{array}{l}
F_{i, x}=\frac{F_{i}\left(X_{i}-X_{i-1}\right)}{\sqrt{\left(X_{i}-X_{i-1}\right)^{2}+\left(Y_{i}-Y_{i-1}\right)^{2}}} \\
F_{i, y}=\frac{F_{i}\left(Y_{i}-Y_{i-1}\right)}{\sqrt{\left(X_{i}-X_{i-1}\right)^{2}+\left(Y_{i}-Y_{i-1}\right)^{2}}}
\end{array}\right.
$$

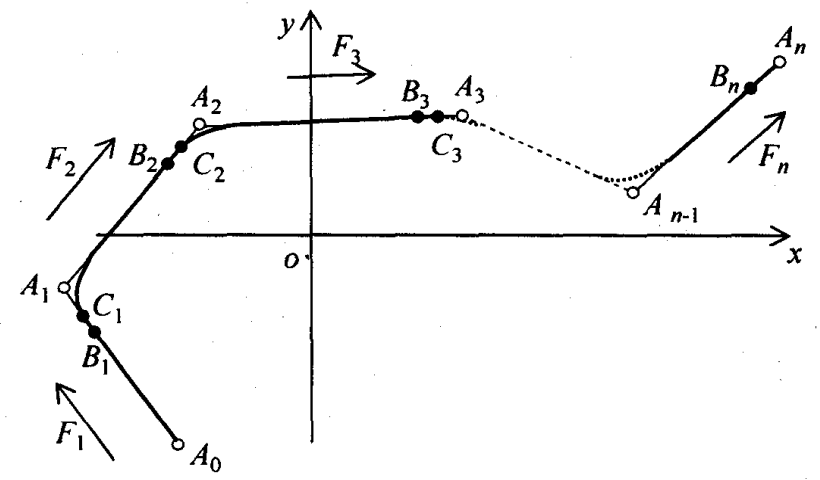

Fig. 8 Cutter path consisted of linear segments

直線セグメントが短い場合に対して，先行セグメン ト間の加減速運動の影響が後続セグメントの運動にも 及ぶことを想定し, かつ, 工具経路軌跡のシミュレー ション計算を容易に遂行することを考慮して，本研究 では，各補間セグメントの加減速運動がそれぞれ独立 に作動し，それらの合成運動にようて工具経路の軌跡 を決めるという前提条件を工具経路軌跡のシミュレー ションに取り入れる、また，シミュレーションに必要 な各セグメントの減速運動の開始タイミングと駆動軸 が減速開始から完全に停止するまでの減速運動の作動 時間については次のように決める.

\section{$3 \cdot 1$ 各セグメントの成速迋均開蛞タイミング}

各セグメントの減速運動開始のタイミングに関して は, 各駆動軸の減速運動が式 (3) の関係を満足するとい う仮定の下で, 駆動軸サーボ系時定数 $T_{x}$ と $T_{y}$ の值と無 関係に次の関係が成立する（付録を参照）。

$$
\Delta t_{i}=\frac{\sqrt{\left(X_{i}-X_{i-1}\right)^{2}+\left(Y_{i}-Y_{i-1}\right)^{2}}}{F_{i}}
$$

ここで, $\Delta t_{i}$ は $i$ 番目セグメントが加速運動開始点 $C_{i-1}$ （i=1 の場合は点 $A_{0}$ ） から減速運動開始点 $B_{i}$ までの運 動時間である. その值は $i$ 番目セグメントの公称送り時 間（式(7)右辺の值）と等しい. 一方, 式(5)に示した ように，セグメントの減速運動開始点と次のセグメン トの加速運動開始点との閐に対応する時間は $\Delta t$ である. したがって，最後のセグメント以外に各セグメントの 実行時間は $\Delta t_{i}+\Delta t(i=1,2, \ldots, n-1)$ となる.

以下では，区別するために，MCの運動開始からの累 積時間を $t$, 各セグメントの加速過程と減速過程を記述 する動作時間を $\tau$ と記す.

3-2 減速迋为の作㽖時間式(1)の定義によれば， 駆動軸が減速開始から完全停止までかかる時間は理論 上無限大になる. シミュレーションではこの問題を次 のように処理する。 
駆動軸 $x$ は, $i$ 番目セグメントの减速運動開始点 $B_{i}$ で公称送り速度 $F_{i, x}$ から減速し始め, セグメントの指令 終点位置 $X_{i}$ に十分近い位置 $\left(X_{i} \pm \delta\right)$ に到達すると運動 が止まるとする．したがって，式(3)に基づいて，停止 位置に到達する減速運動の時間 $\Delta T$ は次式から求めるこ とができる.

$$
\left|F_{i, x} T_{x}-\int_{0}^{\Delta T} F_{i, x} e^{-\frac{\tau}{T_{x}}} \mathrm{~d} \tau\right|<\delta
$$

駆動軸 $y$ についても同様に考える.

式(8)の関係に基づいて，計算を簡単にするためにシ ミュレーションの中では次式による $\Delta T$ の值を使う.

$$
\left\{\begin{array}{l}
\Delta T=T_{\max } \log _{e}\left\{\left(F_{i, *}\right)_{\max } T_{\max } / \delta\right\} \\
T_{\max }=\max \left(T_{x}, T_{y}\right) \\
\left(F_{i, *}\right)_{\max }=\max \left(F_{i, x}, F_{i, y}\right) \quad(i=1,2, \cdots, n)
\end{array}\right.
$$

したがって, $n$ 番目セグメントの運動実行時間は $\Delta_{n}+\Delta T$ となる。また，シミュレーション計算に $\delta$ の值として $1 \mu \mathrm{m}$ を用いた.

$3 \cdot 3$ シミュレーションアルコリススム 上述の結 果に基づいて, 工具経路軌跡のシミュレーションアル ゴリズムは以下のようになる.

(a) $i=1$ とする. 点 $A_{0}$ から点 $B_{1}$ までの駆動軸速度 $v_{x}(\tau)$ と $v_{y}(\tau)$ を式(10) から, 工具経路軌跡 $x(\tau)$ と $y(\tau)$ を式(11) から計算する.

$$
\begin{aligned}
& v_{m}(\tau)=F_{1, m}\left(1-e^{-\frac{\tau}{T_{m}}}\right) \\
& m(\tau)=F_{1, m} \tau-F_{1, m} T_{m}\left(1-e^{-\frac{\tau}{T_{m}}}\right)+M_{0}
\end{aligned}
$$

ただし，動作時間 $\tau$ は次式による.

$$
0 \leq \tau=t \leq \Delta t_{1}
$$

ここで，式の記述を簡明にするために，個々の駆動軸 を表す記号 $x, y$ の代わりに共通の記号 $m$, 個々の座標 $X, Y$ の代わりに共通の記号 $M$ を使用する. 個々の駆動 軸の送り速度と軌跡を計算するとき, $\boldsymbol{m}$ と $M$ の筫所に 対応する軸の $x$ と $X$, または, $y$ と $Y$ を置き換えればよ い. 誤解を起こさない限り後述の式も同様に取り扱う.

一方, 点 $B_{1}$ から点 $C_{1}$ までの駆動軸速度を式(13)から, 工具経路軌跡を式(14)から計算する.

$$
v_{m}(\tau)=F_{1, m}\left(1-e^{-\frac{\Delta_{1}}{T_{m}}}\right) e^{-\frac{\tau}{T_{m}}}
$$

$$
m(\tau)=F_{1, m}\left(1-e^{-\frac{\Delta t_{1}}{T_{m}}}\right) T_{m}\left(1-e^{-\frac{\tau}{T_{m}}}\right)+\dot{m}_{B 1}
$$

ただし，動作時間 $\tau$ は次式による.

$$
0<\tau=t-\Delta t_{1} \leq \Delta t
$$

(b) $i=i+1$ と置き換える. 点 $C_{i-1}$ から点 $B_{i}$ までの駆動 軸速度と工具経路軌跡をそれぞれ式(16) と式(17) から 計算する.

$$
v_{m}(\tau)=F_{i, m}\left(1-e^{-\frac{\tau}{T_{m}}}\right)+\sum_{j=J}^{i-1} F_{j, m}\left(1-e^{-\frac{\Delta t_{j}}{T_{m}}}\right) e^{-\frac{\tau+t_{i-1}-t_{j}+\Delta t}{T_{m}}}
$$

$$
\begin{aligned}
& m(\tau)=F_{i, m} \tau-F_{i, m} T_{m}\left(1-e^{-\frac{\tau}{T_{m}}}\right)+m_{C, j-1}+ \\
& \sum_{j=J}^{i-1}\left\{F_{j, m}\left(1-e^{-\frac{\Delta \Delta_{j}}{T_{m}}}\right) T_{m} e^{-\frac{t_{i-1}-t_{j}+\Delta \Delta}{T_{m}}}\left(1-e^{-\frac{\tau}{T_{m}}}\right)\right\}
\end{aligned}
$$

ただし，動作時間 $\tau$ は次式による.

$$
\left\{\begin{array}{l}
0<\tau=t-t_{i-1}-\Delta t \leq \Delta t_{i} \\
t_{i-1}=\sum_{j=1}^{i-2}\left(\Delta t_{j}+\Delta t\right)+\Delta t_{i-1}
\end{array}\right.
$$

式(16)と（17）におおるJは次式を満たす最小の $j$ とする.

$$
t_{i-1}+\Delta t-\Delta T<t_{j} \quad(j=1,2, \cdots, i-1)
$$

(c) 点 $B_{i}$ から点 $C_{i}$ までの駆動軸速度と工具経路軌跡 をそれぞれ式(20)と式(21)から計算する.

$$
\begin{aligned}
& v_{m}(\tau)=\sum_{j=J}^{i} F_{j, m}\left(1-e^{-\frac{\Delta t_{j}}{T_{m}}}\right) e^{-\frac{\tau+t_{i}-t_{j}}{T_{m}}} \\
& m(\tau)=\sum_{j=J}^{i}\left\{F_{j, m}\left(1-e^{-\frac{\Delta \Delta_{j}}{T_{m}}}\right) T_{m} e^{-\frac{t_{i}-t_{j}}{T_{m}}}\left(1-e^{-\frac{\tau}{T_{m}}}\right)\right\}+m_{B, i}
\end{aligned}
$$

ただし，動作時間 $\tau$ は次式による.

$$
\left\{\begin{array}{l}
0<\tau=t-t_{i} \leq \Delta t, \quad \text { for } i \neq n \\
0<\tau=t-t_{n} \leq \Delta T, \quad \text { for } i=n
\end{array}\right.
$$

（d）i=nならば(b)へ戻る，i=nならば，計算を終了す る.

上述のように，各セグメントの加速運動に対する時 間 $\Delta t_{i}$, 減速運動開始から次のセグメントの加速運動開 始までの時間 $\Delta t$, および最後のセグメントの減速運動 の作動時間 $\Delta T$ が前もって簡単に決められるので, 提案 
Table 1 Motion conditions for test cutter path

\begin{tabular}{|c|c|l|}
\hline $\begin{array}{c}\text { Side length } L \\
(\mathrm{~mm})\end{array}$ & $\begin{array}{c}\text { Feed rate } F \\
(\mathrm{~mm} / \mathrm{min})\end{array}$ & Motion direction \\
\cline { 1 - 2 } 5 & 500,1000, & $\begin{array}{l}\text { Clockwise, } \\
\text { Counter clockwise }\end{array}$ \\
\hline 2 & 2000,5000 & \\
\cline { 1 - 1 } &
\end{tabular}

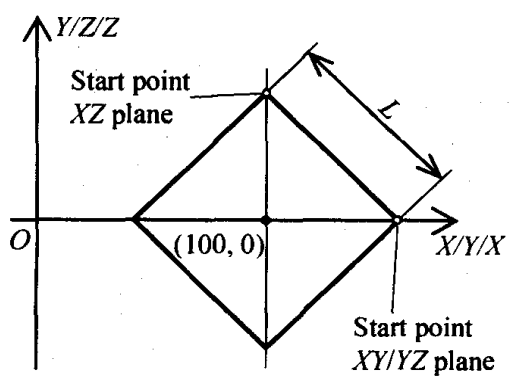

Fig. 9 Measured motion trajectories

アルゴリズムに基づく計算プログラムの作成は簡単に できる.

また，わずかな修正を施せば，提案アルゴリズムは， 補間セグメントのつながり点でドウェルを設けた工具 経路や 3 次元直線補間による工具経路にも適用できる。

\section{4. 工具経路谁動轨跡検証实験の結果}

提案したシミュレーション方法の妥当性を確認する ために, 本章では, $\mathrm{MC}$ 運動軌跡のシミュレーション結 果を運動軌跡の実測結果および加工したワークの輪郭 と比較して検討を加える.

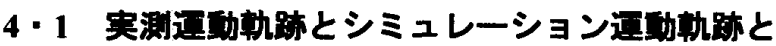

の比较 $\mathrm{LM}$ 測定装置を使用して供試 MC の $X Y$ 平面, $Y Z$ 平面と $X Z$ 平面に図 9 に示す正方形連動の軌跡を測 定した。この運動経路は連続３周まわりで，つながり 点にドウェルを設けない合計 12 個の直線セグメントか らなる．実験経路の運動条件を表 1 に示す．また，運 動軌跡について 1 周当たりに等時間間隔で約 1500 点を 記録した。

図 10 に辺長 $L=5 \mathrm{~mm} \sigma \mathrm{MC}$ 運動軌跡の実測結果とシ ミュレーション結果との比較例を示す．図中の矢印は 運動方向を示す．図からわかるように，実測運動軌跡 はシミュレーション軌跡とよく一致している. 図 10 の 実測運動軌跡を数値微分して得られた駆動軸の速度成 分とシミュレーション速度成分を図 11 に示す. 数值微 分に起因した高周波数の変動成分が見られるが，実測 軌跡による速度成分曲線はシミュレーション曲線とよ く一致していることがわかる.

図 12 と図 13 にそれぞれ $L=2 \mathrm{~mm}$ と $L=1 \mathrm{~mm}$ の $\mathrm{MC}$ 運動軌跡の実測結果とシミュレーション結果との比較

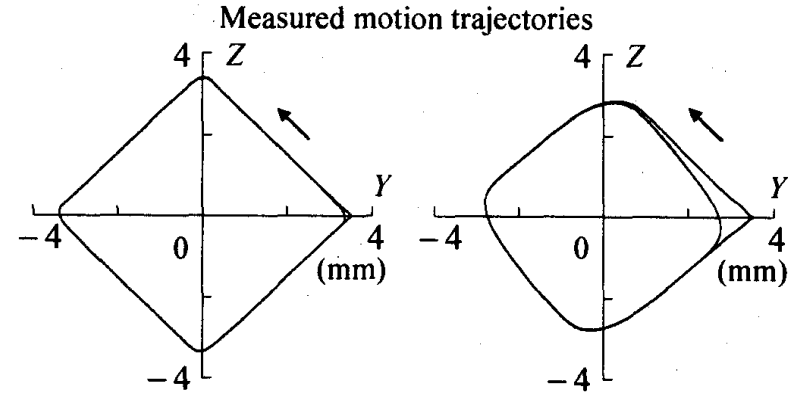

Estimated motion trajectories

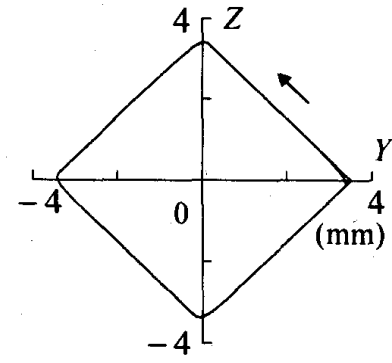

$F=1000(\mathrm{~mm} / \mathrm{min})$

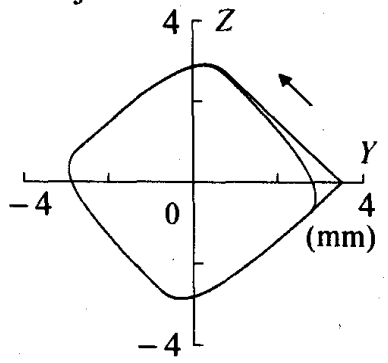

$F=5000(\mathrm{~mm} / \mathrm{min})$
Fig. 10 Comparison example of motion trajectories between estimation and measurement $(L=5 \mathrm{~mm})$
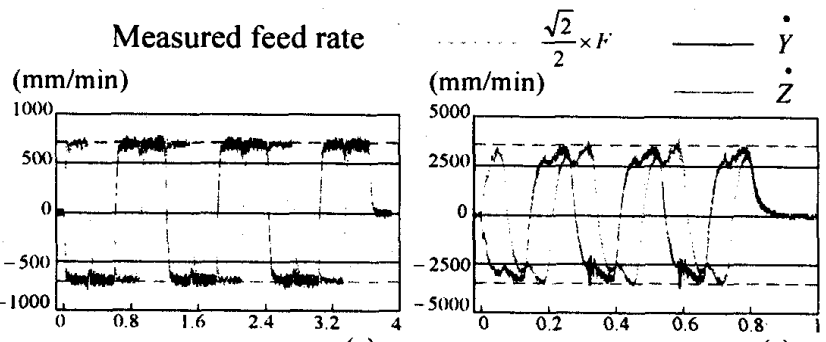

(s)

(s)

Estimated feed rate

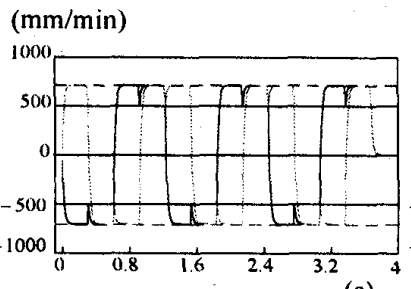

$F=1000(\mathrm{~mm} / \mathrm{min})$

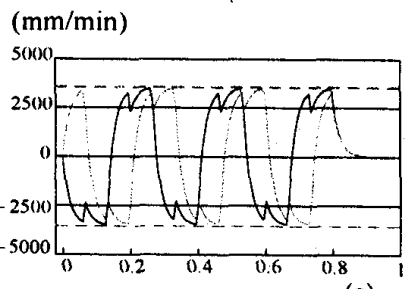

$F=5000(\mathrm{~mm} / \mathrm{min})$
Fig. 11 Comparison example of feed rates corresponding to the motion trajectories in Fig. 10

例を示す. $L=2 \mathrm{~mm}$ の場合に, シミュレーション運動軌 跡と比べて，実測曲線角部の曲り半径がシミュレーシ ヨン曲線のそれより大きくなり，F=5000 mm/min のと きは実測曲線の直線部分もやや曲るように見える. $L=1$ $\mathrm{mm}$ の場合にはこの傾向がより顕在に見られる.この現 象は供試 MC 駆動軸の運動方向の逆転におけるスティ ックモーションやロストモーションならびに MC のバ ックラッシュ補正の影響によるものと思われる(8),(9),(11). また，実測運動軌跡においては，スケールの関係によ って, 連動経路の辺長 $L$ が短ければ短いほど, 補間セ 


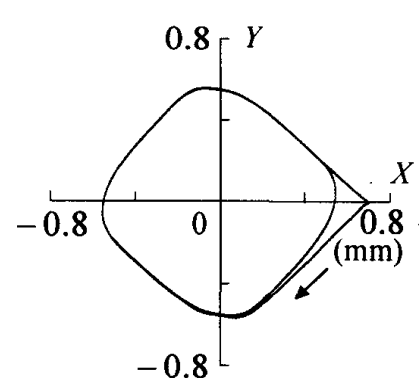

Measured motion trajectories
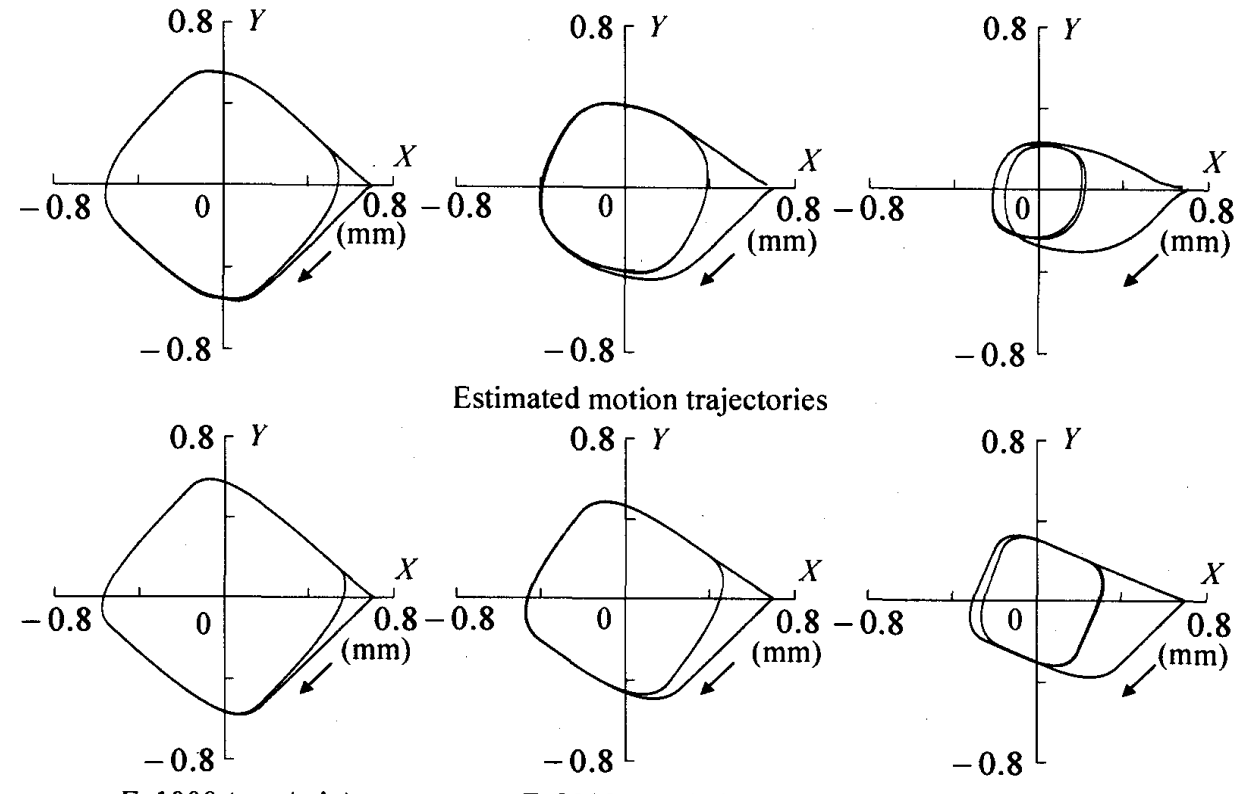

Estimated motion trajectories

$F=1000(\mathrm{~mm} / \mathrm{min})$
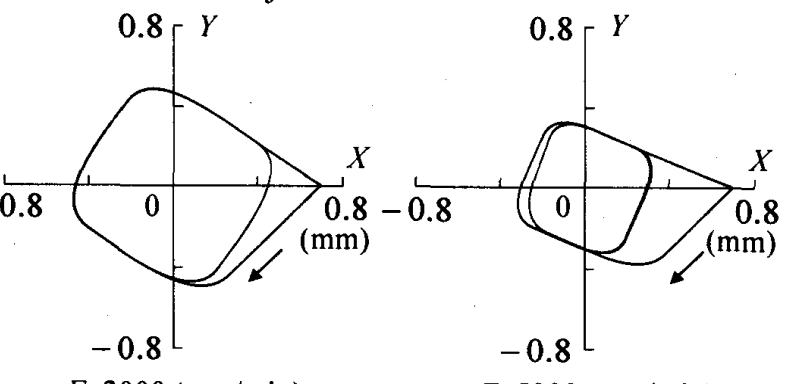

$F=2000(\mathrm{~mm} / \mathrm{min})$

$F=5000(\mathrm{~mm} / \mathrm{min})$

Fig. 13 Comparison example of motion trajectories between estimation and measurement $(L=1 \mathrm{~mm})$
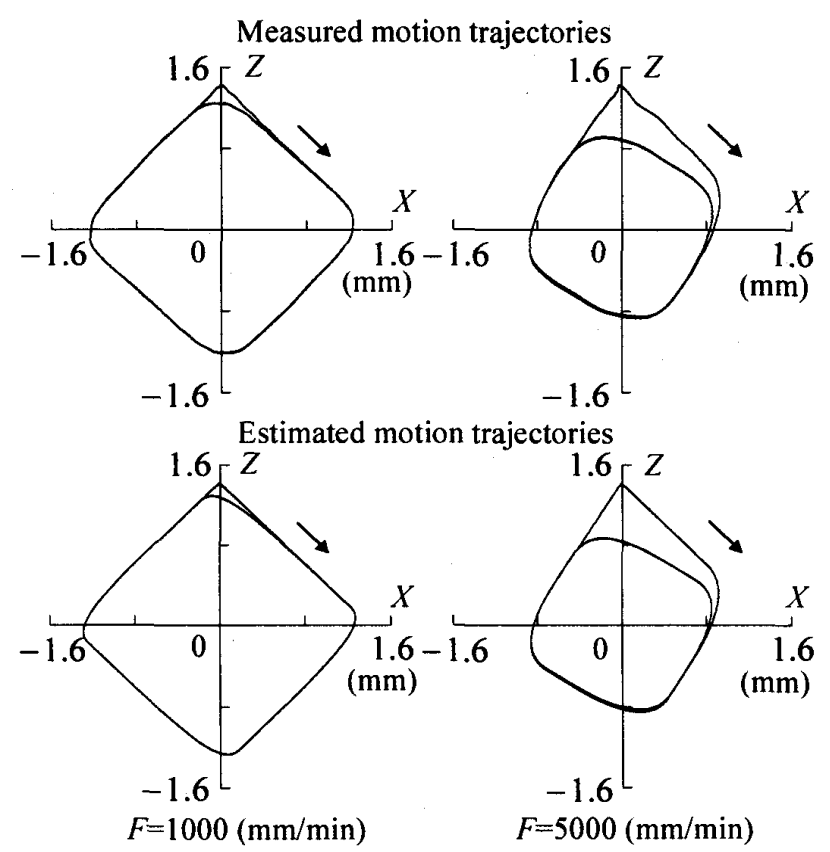

Fig. 12 Comparison example of motion trajectories between estimation and measurement $(L=2 \mathrm{~mm})$

グメント間の加減速運動に対してそれ以外の要因の影 響が視覚的に大きく映され，より顕著に見られる.

図 14 に図 12 の実測連動軌跡を数值微分して得られ た駆動軸の速度成分とシミュレーション速度成分を示 す. 運動軌跡のサンプル点間隔が短くなるので，実測 結果による運動速度成分曲線に数值微分に起因する高 周波数の変動成分が大きくなっているが(10), 実測結果 による曲線とシミュレーション曲線との対応は確認で
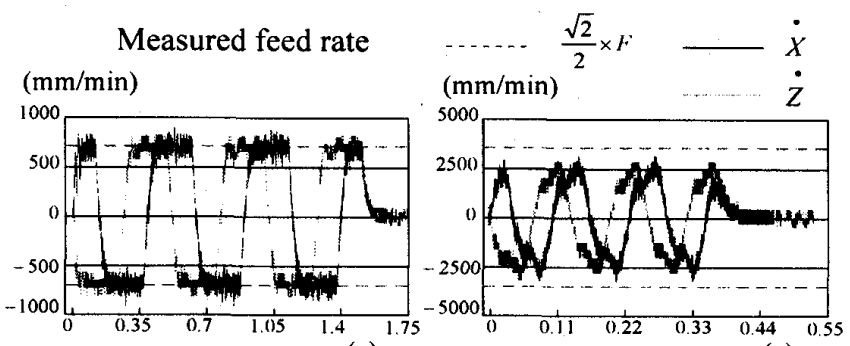

(s)

(s)

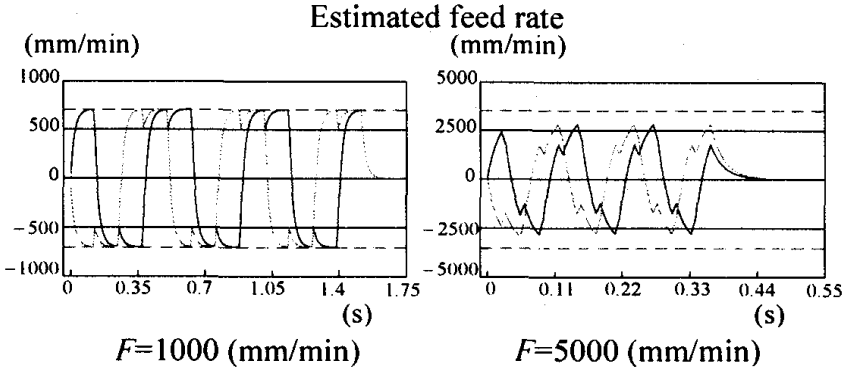

Fig. 14 Comparison example of feed rates corresponding to the motion trajectories in Fig. 12

きる. また, 図 11 と図 14 からわかるように, 運動軌 跡の辺長 $L=5 \mathrm{~mm}$ の場合, 各駆動軸の奏送り速度の最 大值がほぼ指令值に達したが, 運動軌跡の辺長 $L=2 \mathrm{~mm}$ の場合は，指令送り速度が増大するにつれて駆動軸の 実送り速度の最大值が指令值に大幅に及ばなかった。 その結果, 運動軌跡の寸法も指令寸法よりはるかに小 さくなっている.

一方，図 14 に示したように，辺長 $L$ が短い場合に， 指令送り速度の増加によって, MC の実運動時間は公称 送り時間より大幅に増加している。これは各補間セグ 


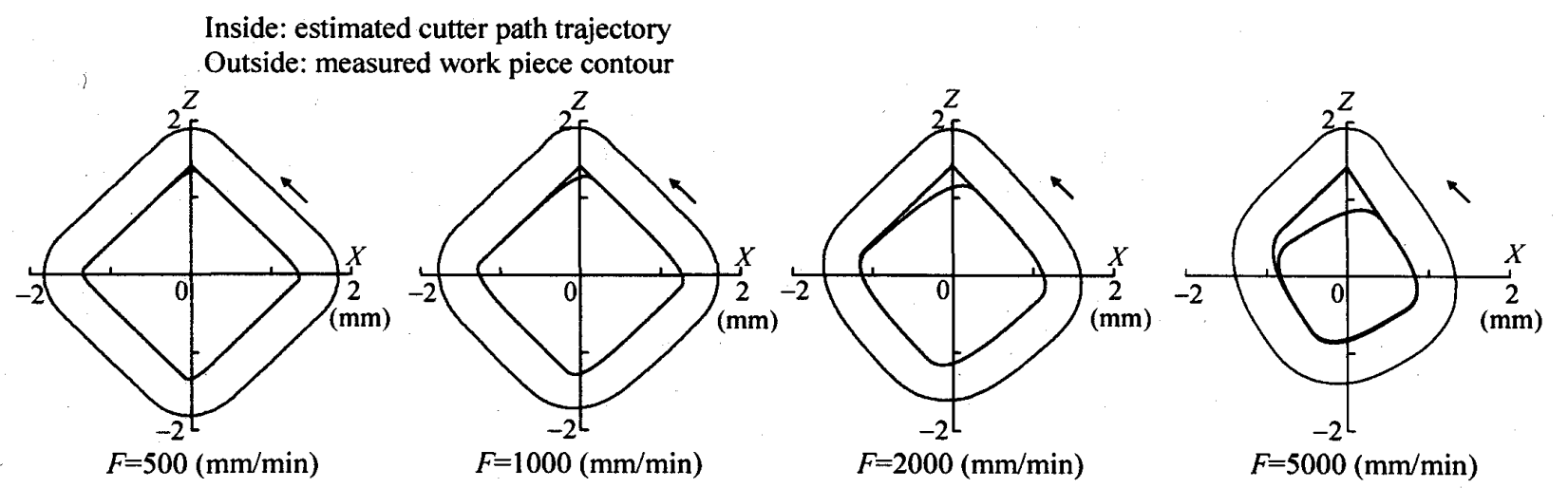

Fig. 15 Comparison example of estimated cutter path trajectories with measured work piece contours

メントの公称送り時間 $\Delta t_{i}$ に対する補間セグメント間の $\mathrm{NC}$ 処理時間 $\Delta t$ と最終セグメントの停止時間 $\Delta T$ の割合 が大きくなるからである. 例えば， $L=2 \mathrm{~mm}, F=5000$ $\mathrm{mm} / \mathrm{min}$ の場合に運動経路の公称送り時間 $0.288 \mathrm{~s}$ に対 して，セグメントの NC 処理時間の合計が $0.077 \mathrm{~s}, \Delta T$ が $0.150 \mathrm{~s}$ であり， $\mathrm{MC}$ の総運動時間は $0.515 \mathrm{~s}$ となる.

また，ほかの運動条件で行った測定実験について検 討した結果も上述と同様になっている.

\section{2 実加エしたワーク輪郭とシミュレーションエ} 具経路通的勒跡との比㪍 直径 $3 \mathrm{~mm}$ のエンドミル とナカニシ製の HES500 型高速スピンドルを使用して, 供試 $\mathrm{MC}$ 上で厚さ $3 \mathrm{~mm}$ の A5052 アルミ板に四方形の 通し穴を加エした. エンドミルの送り平面をそれぞれ $\mathrm{MC}$ の $X Y$ 平面, $Y Z$ 平面および $X Z$ 平面に設定し, 工具 中心の経路を図 9 に示した経路を用いた. ただし，正 方形の辺長 $L$ の指令值を $2 \mathrm{~mm}$ にした. 表 2 に切削条件 を示す。

切削実験の際, $X Y$ 平面の工具経路の場合に, 高速ス ピンドルを $\mathrm{MC}$ の主軸に，ワーク材を $\mathrm{MC}$ のテーブル に取り付ける. 切削中に $\mathrm{MC}$ の主軸を回転させず，高 速スピンドルはそのコントローラに設定された回転数 でエンドミルを回転させる. NC プログラムによってテ 一ブルを駆動しワーク材を送る. 一方, $Y Z$ 平面と $X Z$ 平面の工具経路の場合はワーク材を $\mathrm{MC}$ の主軸に固定 し，高速スピンドルをテーブルに取り付けて送らせる. 加工したワークの輪郭測定においては，ミツトヨ製の BHN506 型三次元測定機を使用して輪郭 1 周に 520 点 を測定した．使用するプローブの直径は $2 \mathrm{~mm}$ である.

図 15 に実測したワーク輪郭とシミュレーションした $\mathrm{MC}$ の工具経路軌跡との比較例を示す. 図を見やすくす るために，プローブ半径を補正せずに測定点に対する プローブ中心の座標を用いてワーク輪郭を表示してい る.したがって, 使用したエンドミルとプローブ直径 の関係から，図示するワーク輪郭は工具経路の外側軌
Table 2 Machining conditions for work piece

\begin{tabular}{|c|c|c|}
\hline \multirow{4}{*}{$\begin{array}{c}\text { Cutting } \\
\text { conditions }\end{array}$} & $\begin{array}{c}\text { Spindle speed } S(\mathrm{rpm}) / \\
\text { Feed rate } F(\mathrm{~mm} / \mathrm{min})\end{array}$ & $\begin{array}{c}10000 / 500, \\
20000 / 1000, \\
30000 / 2000, \\
50000 / 5000\end{array}$ \\
\cline { 2 - 3 } & Radial depth of cut $(\mathrm{mm})$ & 0.1 \\
\cline { 2 - 3 } & Axial depth of cut $(\mathrm{mm})$ & 3 \\
\hline \multirow{4}{*}{ End mill } & Diameter $(\mathrm{mm})$ & 3 \\
\cline { 2 - 3 } & Flute number & 2 \\
\cline { 2 - 3 } & Helix angle $\left(^{\circ}\right)$ & 30 \\
\cline { 2 - 3 } & Material & $\begin{array}{c}\text { CO-HSS+TiN } \\
\text { coating }\end{array}$ \\
\hline \multirow{3}{*}{ Workpiece } & Material & $\begin{array}{c}\text { Duralumin } \\
\text { A5052 plate }\end{array}$ \\
\cline { 2 - 3 } & Thickness (mm) & 3 \\
\cline { 2 - 3 } & & \\
\hline
\end{tabular}

跡を $0.5 \mathrm{~mm}$ 方フセットした曲線に相当する. 図からわ かるように，工具経路の開始・終了部を含めてシミュ レーションした運動軌跡はワーク輪郭に一致している. ほかの運動平面に加エしたワークの輪郭も同様な結果 となっている.

前節と本節に述べた検証実験の結果から，提案した MC 工具経路軌跡のシミュレーション方法は妥当であ ることが確認された。

\section{5. 結}

本研究では, MC の使用者の立場から, セグメント間 の NC 加減速運動に起因する MC の直線補間工具経路 の誤差推定方法を検討した．その結果をまとめると， 以下の通りである.

（1）極少回数の簡単な $\mathrm{MC}$ 直線運動の軌跡測定結果 に基づいて, 補間セグメント間の指数関数形 NC 加減 速制御パラメータを同定する方法を提案した。 また, 同定結果を用いて推定した工具経路の軌跡を実測した MC の運動軌跡と比較することにより，提案した方法の 有効性を確認した. 提案方法の基本的考え方はほかの $\mathrm{NC}$ 加減速運動制御方式のパラメータ同定にも適用可 
能である.

（2）多数の短い直線セグメントからなる工具経路を 対象とし, MC の加減速運動制御パラメータに基づいて, 工具経路軌跡を簡便にシミュレーションする方法を提 案した. また, 工具経路軌跡のシミュレーション結果 を実測した工具経路軌跡および加工したワーク輪郭と 比較することにより，提案したシミュレーション方法 の妥当性を確認した. その結果, 切削実験をせずに工 具経路に及ぼす補間セグメント間の NC 加減速運動の 影響を推定して把握することが可能となった。

最後に, MC の補間セグメント間の NC 加減速運動の 影響に関してソフトウェアとハードウェアの両面から 種々の改善対策が提案され ${ }^{(15),(16)}, \mathrm{MC}$ の加工精度が大 幅に向上している今日にも，試切削をせずに NC 加減 速運動の影響を把握し, 切削パラメータの妥当性を検 討できる点では，MCの使用者にとって，本研究に提案 した方法は実用上意義があると思われる.

\section{付録：数学带納法による式 (7)の証明}

式(3)に基づいて，1 番目セグメントの減速運動開始 点 $B_{1}$ において駆動軸速度 $v_{m}(\tau)$ と工具経路軌跡 $m(\tau)$ は次 式を満足する.

$$
v_{m}(\tau) T_{m}=M_{1}-m(\tau)
$$

式(10)と（11）を上式に代入して整理すると，点 $B_{1}$ にお ける時間 $\tau$ につて次の関係が得られる.

$$
\tau=\frac{X_{1}-X_{0}}{F_{1, x}}=\frac{Y_{1}-Y_{0}}{F_{1, y}}=\frac{\sqrt{\left(X_{1}-X_{0}\right)^{2}+\left(Y_{1}-Y_{0}\right)^{2}}}{F_{1}}
$$

点 $A_{0}$ を基準として，点 $C_{1}$ から点 $B_{2}$ までの 2 番目セ グメントの駆動軸速度と工具経路軌跡は次の式で記述 できる. ただし， $0 \leq \tau=t-\Delta t_{1}-\Delta t$ である.

$$
\begin{gathered}
v_{m}(\tau)=F_{2, m}\left(1-e^{-\frac{\tau}{T_{m}}}\right)+F_{1, m}\left(1-e^{-\frac{\Delta \Delta_{1}}{T_{m}}}\right) e^{-\frac{\tau+\Delta t}{T_{m}}} \\
m(\tau)=F_{2, m} \tau-F_{2, m} T_{m}\left(1-e^{-\frac{\tau}{T_{m}}}\right)+F_{1, m} \Delta t_{1}- \\
F_{1, m}\left(1-e^{-\frac{\Delta_{1}}{T_{m}}}\right) T_{m}\left(1-e^{-\frac{\tau+\Delta}{T_{m}}}\right)+M_{0}
\end{gathered}
$$

式(3)に基づき，点 $B_{2}$ において次式が成立つ.

$$
v_{m}(\tau) T_{m}=M_{2}-m(\tau)
$$

式(25)と（26）を式(27)に代入し整理すると,

$$
\begin{aligned}
F_{2, m} \tau & =M_{2}-F_{1, m} \Delta t_{1}-M_{0} \\
& =M_{2}-M_{1}+M_{1}-M_{0}-F_{1, m} \Delta t_{1}
\end{aligned}
$$

よって, 点 $B_{2}$ における時間 $\tau$ に対して次式が成立する.

$$
\tau=\frac{X_{2}-X_{1}}{F_{2, x}}=\frac{Y_{2}-Y_{1}}{F_{2, y}}=\frac{\sqrt{\left(X_{2}-X_{1}\right)^{2}+\left(Y_{2}-Y_{1}\right)^{2}}}{F_{2}}
$$

次に, $i-1$ 番目のセグメントまでに各セグメントの加 速運動開始点から減速運動開始点までの動作時間 $\tau$ が すべて式(7)を満たすとする，点 $A_{0}$ を基準にして，点 $C_{i-1}$ から点 $B_{i}$ までの $i$ 番目セグメントの駆動軸速度と 運動軌跡は次の式で記述できる.ただし， $0 \leq \tau=t-t_{i-1}-\Delta t$ である。

$$
\begin{aligned}
v_{m}(\tau)= & F_{i, m}\left(1-e^{-\frac{\tau}{T_{m}}}\right)+\sum_{j=1}^{i-1}\left\{F_{j, m}\left(1-e^{-\frac{\Delta t_{j}}{T_{m}}}\right) e^{-\frac{\tau+t_{i-1}-t_{j}+\Delta t}{T_{m}}}\right\} \\
m(\tau)= & F_{i, m} \tau-F_{i, m} T_{m}\left(1-e^{-\frac{\tau}{T_{m}}}\right)+M_{0}+ \\
& \sum_{j=1}^{i-1}\left\{F_{j, m} \Delta t_{j}-F_{j, m} T_{m}\left(1-e^{-\frac{\Delta t_{j}}{T_{m}}}\right)\right\}+ \\
& \sum_{j=1}^{i-1}\left\{F_{j, m}\left(1-e^{-\frac{\Delta y_{j}}{T_{m}}}\right) T_{m}\left(1-e^{-\frac{\tau+t_{i-1}-t_{j}+\Delta t}{T_{m}}}\right)\right\}
\end{aligned}
$$

式(3)に基づき，点 $B$ ににおいて次式が成立つ.

$$
v_{m}(\tau) T_{m}=M_{i}-m(\tau)
$$

式(29)と（30）を式(31)に代入し整理すると,

$$
F_{i, m} \tau=M_{i}-M_{0}-\sum_{j=1}^{i-1} F_{j, m} \Delta t_{j}
$$

よって，点 $B_{i}$ における時間 $\tau$ は次のように表される.

$$
\begin{aligned}
\tau= & \frac{M_{i}-M_{i-1}}{F_{i, m}}+\frac{M_{i-1}-M_{i-2}}{F_{i, m}}+\cdots+\frac{M_{1}-M_{0}}{F_{i, m}}- \\
& \sum_{j=1}^{i-1} \frac{F_{j, m}}{F_{i, m}} \times \frac{\sqrt{\left(X_{j}-X_{j-1}\right)^{2}+\left(Y_{j}-Y_{j-1}\right)^{2}}}{F_{j}} \\
= & \frac{M_{i}-M_{i-1}}{F_{i, m}}=\frac{\sqrt{\left(X_{i}-X_{i-1}\right)^{2}+\left(Y_{i}-Y_{i-1}\right)^{2}}}{F_{i}}
\end{aligned}
$$

すなわち, 点 $C_{i-1}$ から点 $B_{i}$ までの $i$ 番目セグメントの 動作時間 $\tau$ も式(7) を満足する.

\section{文 都}

(1) Kwon, H. D. and Burdekin, M., Adjustment of CNC Machine Tool Controller Setting Values by an Experimental Method, International Journal of Machine Tools \& Manufacture, Vol. 38, No. 9 (1998), pp. 1045-1065.

(2) Qiu, H., Takeshita, Y. and Takada, M., New Measurement Method for Motion Accuracy of NC Machine Tools by Link Mechanism (3rd Report, 
Measurement of Accuracy for Circular Motion with a Small Radius and Linear Motion Containing a Square Corner), Transactions of the Japan Society of Mechanical Engineers, Series C, Vol. 64, No. 628 (1998), pp. 4850-4856.

(3) Schmitz, T. and Ziegert, J., Dynamic Evaluation of Spatial CNC Contouring Accuracy, Precision Engineering, Vol. 24, No. 2 (2000), pp. 99-118.

(4) Shih, Y.-T., Chen, C.-S. and Lee, A.-C., Path Planning for $\mathrm{CNC}$. Contouring around a Corner, JSME International Journal, Series C, Vol. 47, No. 1 (2004), pp. $412-420$.

(5) Matsubara, A., Hatozaki, T. and Ibaraki, S., Analysis of Motion Error of CNC Machine Tools (1st Report)Analysis of Motion Error at the Corner-, Proceedings of the 5th Manufacturing \& Machine Tool Conference, No. 04-3 (2004), pp. 119-120.

(6) Yan, X., Shirase, K. Kawabata, H., Hirao, M. and Yasui, T., Improving Productivity of Machining Centers Based on NC Program Diagnostic System (1st Report) - Evaluation of Productivity Using NC Program Simulator-, Journal of the Japan Society for Precision Engineering, Vol. 63, No. 7 (1997), pp. 1044-1048.

(7) FANUC LTD Co., The Instruction Manual of FANUC Series 0-MB, (1987), pp. 32-33, FANUC LTD Co.

(8) Qiu, H., Kubo, A., Li, Z.-Y. and Ikegami, H., Measurement of Machining Center Motion Trajectories within a Small Area, Transactions of the Japan Society of Mechanical Engineers, Series C, Vol. 72, No. 716 (2006), pp. 1034-1040.

(9) Kubo, A. and Qiu, H., Measurement of Small Size Motion Trajectories on Vertical Planes of Machining Center, Journal of Japan Society for Design Engineering, Vol. 42, No. 7 (2007), pp.413-418.
(10) Qiu, H., Velocity Measurement for Planar Motions of Machines Using the LM Measuring Device, Journal of Robotics and Mechatronics, Vol. 10, No. 4 (1998), pp. 358-363.

(11) Kakino, Y., Ihara, Y. and Nakatsu, Y., A Study on the Motion Accuracy of NC Machine Tools (2nd Report)Diagnosis of Motion Error Origins by Using Double Ball Bar Test -, Journal of the Japan Society for Precision Engineering, Vol. 52, No. 10 (1986), pp. 1739-1745.

(12) Kakino, Y., Ihara, Y., Lin, S., Hayama, S., Kawakami, K. and Hamamura, M., Measurement of Motion Accuracy and Improvement of Machining Accuracy on Ultra-High Precision-NC Machine Tools by Using Cross Grid Encoder Test, Journal of the Japan Society for Precision Engineering, Vol. 62, No. 11 (1996), pp.1612- 1616.

(13) Utsumi, K., Measurement Technology for Circular Motion Accuracy, Science of Machine, Vol. 50, No. 1 (1998), pp.201-205.

(14) Yamanaka, M., Verification Method for Motion Accuracy and Servo Performance of Machines Utilization of Motion Analyzer TPC - Science of Machine, Vol. 50, No. 1 (1998), pp.206-212.

(15) Nagashima, K. and Hirose, T., Contouring Path Deviation in CNC Machine Tools and Its Input-Adaptive System, Transactions of the Japan Society of Mechanical Engineers, Series C, Vol. 65, No. 638 (1999), pp. 4230-4236.

(16) Takahashi, N., Iriguchi, K. and Kato, K., High Accuracy Surface Finish Using Surface Driven Interpolation $\mathrm{NC}$ by Acceleration Compensation, Journal of the Japan Society for Precision Engineering, Vol. 71, No. 10 (2005), pp. 1309- 1314. 